\title{
Preliminary in vitro evaluation of the anti-proliferative activity of guanylhydrazone derivatives
}

\author{
PAULO H. B. FRANÇA ${ }^{2}$ \\ EDEILDO F. DA SILVA-JÚNIOR ${ }^{2}$ \\ PEDRO G. V. AQUINO ${ }^{1}$ \\ ANTÔNIO E. G. SANTANA ${ }^{1}$ \\ JAMYLLE N. S. FERRO 3 \\ EMILIANO DE OLIVEIRA BARRETO 3 \\ CLÁUDIA DO Ó PESSOA ${ }^{4}$ \\ ASSUERO SILVA MEIRA ${ }^{4}$ \\ THIAGO M. DE AQUINO ${ }^{2}$ \\ MAGNA S. ALEXANDRE-MOREIRA 5 \\ MARTINE SCHMITT ${ }^{6}$ \\ JOÃO X. DE ARAÚJO-JÚNIOR ${ }^{2 *}$
}

${ }^{1}$ Natural Resources Research Laboratory Institute of Chemistry and Biotechnology

Federal University of Alagoas, Maceio, Brazil

${ }^{2}$ Laboratory of Medicinal Chemistry

School of Nursing and Pharmacy

Federal University of Alagoas, Maceio, Brazil

${ }^{3}$ Cell Biology Laboratory, Biological and Health Sciences, Federal University of Alagoas, Maceio, Brazil

${ }^{4}$ Experimental Oncology Laboratory

Department of Physiology and Pharmacology Federal University of Ceara, Fortaleza, Brazil

${ }^{5}$ Institute of Biological and Health Sciences Laboratory of Pharmacology and Immunity Federal University of Alagoas, Maceio, Brazil

${ }^{6}$ Laboratoire d'innovation Thérapeutique

Faculté de Pharmacie, Université de Strasbourg Illkirck, France

Accepted November 25, 2015

Online published February 11, 2016
Guanylhydrazones have shown promising antitumor activity in preclinical tumor models in several studies. In this study, we aimed at evaluating the cytotoxic effect of a series of synthetic guanylhydrazones. Different human tumor cell lines, by including HCT-8 (colon carcinoma), MDA-MB-435 (melanoma) and SF-295 (glioblastoma) were continuous exposed to guanylhydrazone derivatives for 72 hours and growth inhibition of tumor cell lines and macrophages J774 was measured using tetrazolium salt (MTT) assay. Compounds 7, 11, 16 and 17 showed strong cytotoxic activity with $I C_{50}$ values lower than $10 \mu \mathrm{mol} \mathrm{L}{ }^{-1}$ against four tumor cell lines. Among them, 7 was less toxic to non-tumor cells. Finally, obtained data suggest that guanylhydrazones may be regarded as potential lead compounds for the design of novel anticancer agents.

Keywords: guanylhydrazone, cytotoxic effect, synthesis, MTT assay

\footnotetext{
*Correspondence; e-mail: jotaaranjo2004@gmail.com
} 
Guanylhydrazones represent a class of compounds showing interesting pharmacological activities on several levels; they derive from the same aminoguanidine chemotype with mixed hydrogen bond acceptor and donor properties as well as being able to establish electrostatic interactions $(1,2)$. Moreover, they already led to various active derivatives, as illustrated in Fig. 1 (3). Guanidine derivatives have been reported to be efficient anti-cancer agents. Previous reports showed that $m$-iodobenzylguanidines (MIBG), pyridylcyanoguanidine (CHS 828) and mitoguazone (MGBG) have shown promising antitumor activity in preclinical tumor models, while mitoguazone showed useful clinical activity for the treatment of malignant lymphoma, carcinoma of the head, neck and esophageal and non-small cell lung cancer (4). More recently, a series of imidazo[2,1-b]thiazoleguanylhydrazones was reported for their antitumor activity and was able to induce apoptosis in HT29 and HL-60 cell lines (5). However, no structure-activity relationship of imidazothiazole compounds was available. Sixteen guanylhydrazone coactivator binding inhibitors for estrogen receptor showed good to moderate activity, but no cytotoxicity data were shown for these compounds (6).<smiles>N=C(N)NCc1cccc(I)c1</smiles>
$m$-Iodobenzylguanidines (MIBG)<smiles>N=C(NCCCCCCOc1ccccc1)Nc1ccncc1</smiles>

Pyridylcyanoguanidine (CHS 828)<smiles>CC(/C=N/NC(=N)N)=N\NC(=N)N</smiles>

Mitoguazone (MGBG)<smiles>[R]c1nc2sccn2c1/C=N/NC(=N)N</smiles>

Imidazol $[2,1-b]$ thiazole guanylhydrazone

Fig. 1. Cytotoxic guanylhydrazones previously reported in literature (4).

After identification of the guanidine moiety, as the key pharmacophoric group for activity, we decided to replace the imidazothiazole ring by a phenyl ring, which offered the advantage of scaffold modification. In particular, our objective was to perform a systematic exploration of the aryl group allowing introduction of various substituents at the phenyl ring. The phenyl ring was replaced by heteroaromatics in another series of compounds.

\section{EXPERIMENTAL}

\section{General}

All purchased chemical reagents (Sigma-Aldrich, Brazil) were of the highest purity. Thin layer chromatography was done on aluminum sheets (DC Silicagel 60, Merck, Brazil) and observed under ultraviolet light at 254 and $366 \mathrm{~nm}$ in a Spectroline ${ }^{\circledR}$ ENF-260 CIF 
chamber. NMR spectra $\left({ }^{1} \mathrm{H}: 400 \mathrm{MHz} ;{ }^{13} \mathrm{C}: 100 \mathrm{MHz}\right)$ were obtained from a Bruker ${ }^{\circledR} \mathrm{DPX}$ 500 (Germany) device. All chemical shift values were recorded as $\delta$ (ppm), the coupling constant value $J$ was measured in hertz; the peaks are presented as $s$ (singlet), $d$ (doublet), $t$ (triplet), $d d$ (double doublet), and $m$ (multiplet).

\section{Synthesis of target compounds}

Guanylhydrazones 1-20 were prepared by the reaction of an appropriate aryl aldehyde with aminoguanidine hydrochloride (1:1.25 equiv). The reactants were dissolved in a minimal amount of methanol, heated to reflux, and stirred overnight. Upon cooling to room temperature, products crystallized out from the methanol solution. Products were recovered and dried under vacuum overnight. All reactions were monitored by TLC. The solvent was removed under reduced pressure and the solid was triturated with ethyl acetate yielding the substances as powders.

\section{Assessment of cell viability}

Cytotoxic effects of the synthesized compounds were evaluated against the following human cancer cell lines (National Cancer Institute, Bethesda, MD, USA): HCT-8 (colon carcinoma), SF-295 (glioblastoma) and MDA-MB-435 (melanoma). Tumor cells were seeded in 96-well plates $\left(0.7 \times 10^{5}\right.$ cells per well for adherent cells and $3 \times 10^{5}$ cells $\mathrm{mL}^{-1}$ for suspended cells). After 24 hours, the compounds $\left(5 \mu \mathrm{g} \mathrm{mL}^{-1}\right)$, dissolved in dimethylsulfoxide (DMSO), were added to each well using an automated workstation Biomek ${ }^{\circledR} 3000$ (Beckman Coulter, USA) and incubated for 72 hours. Addition of doxorubicin (Sigma Aldrich Co., USA) at $5 \mu \mathrm{g} \mathrm{mL}^{-1}$ concentrations was performed in $150 \mu \mathrm{L}$ of Roswell Park Memorial Institute (RPMI 1640) medium [2 $\mathrm{mmol} \mathrm{L}^{-1}$ of L-glutamine, $10 \mathrm{mmol} \mathrm{L}^{-1}$ of 4-(2-hydroxyethyl)1-piperazineethanesulfonic acid (HEPES), $1 \mathrm{mmol} \mathrm{L}^{-1}$ of sodium pyruvate, $4.5 \mathrm{~g} \mathrm{~L}^{-1}$ of glucose, $1500 \mathrm{mg} \mathrm{L}^{-1}$ of sodium bicarbonate, $\left.0.5 \mu \mathrm{g} \mathrm{mL}^{-1} \mathrm{MTT}\right]$. After 3 hours, the formazan product was dissolved in $150 \mu \mathrm{L}$ DMSO and the absorbance was measured using a multiplate reader (DTX 880 Multimode Detector, Beckman Coulter). The substance effect was quantified as the percentage of control absorbance at $595 \mathrm{~nm}$.

Macrophage J774 cells were seeded ( $10^{5}$ cells per well) in 96-well flat-bottom microplates. The cells were maintained for 2 hours at $37^{\circ} \mathrm{C}, 5 \% \mathrm{CO}_{2}$ and the medium was replaced with different concentrations of the drugs (10, 100 and $1000 \mu \mathrm{mol} \mathrm{L}^{-1}$ ), in duplicate, and exposed for another 24 hours. Growth controls were also included. Afterwards, MTT solution was added to the cells and plates were returned to the incubator for another 4 hours to evaluate cell viability. This was followed by washing of the wells with $150 \mu \mathrm{L}$ of DMSO for 15 minutes and measurement was performed spectrophotometrically at $540 \mathrm{~nm}$.

\section{RESULTS AND DISCUSSION}

Guanylhydrazone derivatives were obtained through the condensation reaction of benzaldehyde derivatives with aminoguanidine hydrochloride (7, 8; see Scheme 1).

All compounds were characterized by hydrogen $\left({ }^{1} \mathrm{H}\right)$ and carbon $\left({ }^{13} \mathrm{C}\right) \mathrm{NMR}$. The main chemical shifts for each compound are shown in Table I. A signal at $\delta 7.27$ to $9.05 \mathrm{ppm}$ in ${ }^{1} \mathrm{H}$ NMR spectra of all synthesized substances could be observed and was attributed to 
Table I. Spectral data of guanylhydrazones

\begin{tabular}{|c|c|c|}
\hline Compd. & ${ }^{1} \mathrm{H}$ NMR $(\delta, \mathrm{ppm}, \mathrm{Hz})$ & ${ }^{13} \mathrm{CNMR}(\delta, \mathrm{ppm})$ \\
\hline 1 & $\begin{array}{l}7.12(\mathrm{t}, 1 \mathrm{H}, J=7.2), 7.19(\mathrm{t}, 1 \mathrm{H}, J=7.2), 7.45(\mathrm{~d}, 1 \mathrm{H}, \\
J=7.2), 7.8(\mathrm{~s}, 1 \mathrm{H}), 8.28(\mathrm{~d}, 1 \mathrm{H}, J=7.2), 8.36(\mathrm{~s}, 1 \mathrm{H})\end{array}$ & $\begin{array}{c}121.23,122.75,123.27,124.31,132.24 \\
137.51,145.35,155.20\end{array}$ \\
\hline 2 & $\begin{array}{c}7.45(\mathrm{~d}, 2 \mathrm{H}, J=8.5), 7.85(\mathrm{~d}, 2 \mathrm{H}, J=8.5) \\
8.15(\mathrm{~s}, 1 \mathrm{H})\end{array}$ & $\begin{array}{c}129.23,129.70,132.81,135.43,146.01 \\
155.83\end{array}$ \\
\hline 3 & $\begin{array}{c}7.87(\mathrm{~d}, 2 \mathrm{H}, J=8.5), 8.04(\mathrm{~d}, 2 \mathrm{H}, J=8.5) \\
8.24(\mathrm{~s}, 1 \mathrm{H})\end{array}$ & $\begin{array}{c}112.67,119.11,128.60,133.02,138.30 \\
145.36,155.89\end{array}$ \\
\hline 4 & $\begin{array}{c}3.79(\mathrm{~s}, 3 \mathrm{H}), 6.95(\mathrm{~d}, 1 \mathrm{H}, J=8,3), 7.18(\mathrm{dd}, 1 \mathrm{H}, \\
J=8.3 \text { and } 2.0), 7.33(\mathrm{~d}, 1 \mathrm{H}, J=2.0), 8.04(\mathrm{~s}, 1 \mathrm{H})\end{array}$ & $\begin{array}{c}56.11,112.05,113.81,121.09,126.63,147.06, \\
147.62,150.49,155.61\end{array}$ \\
\hline 5 & $\begin{array}{c}3.80(\mathrm{~s}, 6 \mathrm{H}), 6.97(\mathrm{~d}, 1 \mathrm{H}, J=7.9), 7.23(\mathrm{~d}, 1 \mathrm{H}, \\
J=7.9), 7.54(\mathrm{~s}, 1 \mathrm{H}), 8.09(\mathrm{~s}, 1 \mathrm{H})\end{array}$ & $\begin{array}{c}\text { 109.17, 111.60, 123.09, 126.53, 147.39, 149.51, } \\
\text { 151.47, 155.63, 155.70, } 156.16\end{array}$ \\
\hline 6 & $\begin{array}{c}3.81(\mathrm{~s}, 3 \mathrm{H}), 6.83(\mathrm{~d}, 1 \mathrm{H}, J=8.0) ; 7.13(\mathrm{dd}, 1 \mathrm{H}, \\
J=8.0 \text { and } 1.8), 7.50(\mathrm{~s}, 1 \mathrm{H}), 8.04(\mathrm{~s}, 1 \mathrm{H})\end{array}$ & $\begin{array}{c}56.24,110.08,115.67,123.18,125.22,147.74, \\
148.51,149.78,155.52\end{array}$ \\
\hline 7 & $\begin{array}{c}6.83(\mathrm{~d}, 2 \mathrm{H}, J=8.5), 7.66(\mathrm{~d}, 2 \mathrm{H}, J=8.5) \\
8.06(\mathrm{~s}, 1 \mathrm{H})\end{array}$ & $\begin{array}{c}116.06,124.79, \begin{array}{c}129.85,147.52,155.62 \\
160.28\end{array} \\
\end{array}$ \\
\hline 8 & $\begin{array}{c}7.63(\mathrm{~d}, 2 \mathrm{H}, J=8.5), 7.81(\mathrm{~d}, 2 \mathrm{H}, J=8.5) \\
8.17(\mathrm{~s}, 1 \mathrm{H})\end{array}$ & $124.31,129.93,132.15,133.15,146.11,155.79$ \\
\hline 9 & $\begin{array}{c}6.05(\mathrm{~s}, 2 \mathrm{H}), 6.94(\mathrm{~d}, 1 \mathrm{H}, J=8.0), 7.17(\mathrm{dd}, 1 \mathrm{H}, \\
J=8.0 \text { and 1.6), } 7.64(\mathrm{~d}, 1 \mathrm{H}, J=1.6), 8.07(\mathrm{~s}, 1 \mathrm{H})\end{array}$ & $\begin{array}{c}102.03,105.94,108.65,124.80,128.37 \\
146.83,148.45,149.80,155.74\end{array}$ \\
\hline 10 & $1.38(\mathrm{~s}, 18 \mathrm{H}), 7.50(\mathrm{~s}, 2 \mathrm{H}), 8.09(\mathrm{~s}, 1 \mathrm{H})$ & $\begin{array}{c}30.69,35.01,124.99,139.66,148.96,155.53 \\
156.98\end{array}$ \\
\hline 11 & $7.90(\mathrm{~s}, 4 \mathrm{H}), 8.20(\mathrm{~s}, 1 \mathrm{H})$ & $\begin{array}{c}128.07,130.01,132.45,137.86,146.18 \\
155.84,167.36\end{array}$ \\
\hline 12 & $7.45(\mathrm{~m}, 1 \mathrm{H}), 7.57(\mathrm{~d}, 2 \mathrm{H}, J=7.9), 8.42(\mathrm{~s}, 1 \mathrm{H})$ & $129.56,130.01,132.18,134.53,142.99,155.78$ \\
\hline \multirow[t]{2}{*}{13} & $7.72(\mathrm{t}, 1 \mathrm{H}, J=7.5), 7.84(\mathrm{t}, 1 \mathrm{H}, J=7.5), 8.09$ & $119.08,123.89,125.31,128.12,130.14$ \\
\hline & $\begin{array}{c}(\mathrm{d}, 1 \mathrm{H}, J=8.2), 8.40(\mathrm{~d}, 1 \mathrm{H}, J=8.2), 8.18(\mathrm{~d}, 1 \mathrm{H}, \\
J=4.3), 8.98(\mathrm{~d}, 1 \mathrm{H}, J=4.3), 9.05(\mathrm{~s}, 1 \mathrm{H})\end{array}$ & $130.29,137.09,143.47,148.70,150.61,155.77$ \\
\hline 14 & $\begin{array}{c}7.47(\mathrm{~m}, 5 \mathrm{H}), 7.74(\mathrm{~d}, 2 \mathrm{H}, J=8.4), 7.94(\mathrm{~d}, 2 \mathrm{H} \\
J=8.4), 8.24(\mathrm{~s}, 1 \mathrm{H})\end{array}$ & $\begin{array}{l}127.20,127.35,128.44,128.68,129.51 \\
132.94,139.68,142.41,146.95,155.79\end{array}$ \\
\hline 15 & $7.43(\mathrm{~m}, 3 \mathrm{H}), 7.84(\mathrm{~m}, 2 \mathrm{H}), 8.19(\mathrm{~s}, 1 \mathrm{H})$ & $128.03,129.17,130.99,133.81,147.35,155.80$ \\
\hline 16 & $3.84(\mathrm{~s}, 3 \mathrm{H}), 7.98(\mathrm{~s}, 4 \mathrm{H}), 8.25(\mathrm{~s}, 1 \mathrm{H})$ & $\begin{array}{c}2.79,128.19,129.87,131.21,138.25,146.08, \\
155.82,166.30\end{array}$ \\
\hline 17 & $\begin{array}{c}7.68(\mathrm{~d}, 1 \mathrm{H}, J=8.4), 7.79(\mathrm{dd}, 1 \mathrm{H}, J=8.4 \text { and } 2.0) \\
8.24(\mathrm{~d}, 1 \mathrm{H}, J=2.0), 8.16(\mathrm{~s}, 1 \mathrm{H})\end{array}$ & $\begin{array}{c}128.45,129.02,131.33,132.25,133.13 \\
134.66,144.75,155.81\end{array}$ \\
\hline 18 & $\begin{array}{c}7.47(\mathrm{~m}, 2 \mathrm{H}), 7.74(\mathrm{~d}, 1 \mathrm{H}, J=8.0), 8.06(\mathrm{~s}, 1 \mathrm{H}) \\
8.17(\mathrm{~s}, 1 \mathrm{H})\end{array}$ & $\begin{array}{c}126.84,127.30,130.58,131.04,134.19 \\
136.05,145.79,155.81\end{array}$ \\
\hline 19 & $7.36(\mathrm{~m}, 5 \mathrm{H}), 7.49(\mathrm{~m}, 4 \mathrm{H}), 8.06(\mathrm{~s}, 1 \mathrm{H})$ & $\begin{array}{c}126.84,127.30,130.58,131.04,134.19 \\
136.05,145.79,155.81\end{array}$ \\
\hline 20 & $\begin{array}{c}7.60(\mathrm{t}, 2 \mathrm{H}, J=7.8), 7.70(\mathrm{~d}, 1 \mathrm{H}, J=7.8), 8.12 \\
(\mathrm{~d}, 1 \mathrm{H}, J=7.8), 8.21(\mathrm{~s}, 1 \mathrm{H}), 8.31(\mathrm{~s}, 1 \mathrm{H})\end{array}$ & $\begin{array}{c}124.17,125.83,127.15,130.29,132.20 \\
134.95,145.92,123.12,155.74\end{array}$ \\
\hline
\end{tabular}


<smiles>NC(=O)N/N=C/[Te]C(=O)NNC(N)=O</smiles>

Scheme 1

H from imine, since this position is highly deshielded due to the induced anisotropy generated by the bound aromatic ring and the imine double bond. In ${ }^{13} \mathrm{C}$ NMR spectra, the signal related to the imine carbon is usually seen around $\delta 145 \mathrm{ppm}$, whereas the signal ranging from $\delta 155$ to $175 \mathrm{ppm}$ is associated with the highly deshielded quaternary carbon of guanidine moiety.

The cell lines were exposed to derivatives guanylhydrazones $\left(0-5 \mu \mathrm{mol} \mathrm{L}^{-1}\right)$ and positive control: doxorubicin $\left(5 \mu \mathrm{mol} \mathrm{L}{ }^{-1}\right)$ for 72 hours. Experiments were performed in triplicate.

Phenylaminoguanidine 15 exhibits a very low cytotoxic activity, only $20 \%$ inhibition of tumor cell lines at $5 \mu \mathrm{mol} \mathrm{L}{ }^{-1}$. Introduction of an electron-donor group such as hydroxyl or methoxyl 4, 5, 6 and 7 at ortho- and/or para-position did not increase the cytotoxic activity. However, bridging between two groups in 9 induced a slight increase in activity towards the MDA-MB-435 cell line (Table II).

Replacement of the electron-donor group by electron-withdrawing polar groups such as nitrile $\mathbf{3}$ or formyl $\mathbf{1 1}$ showed no significant improvement in potency relative to the parent phenyl group. Introduction of halogen atoms significantly enhanced the activity, as seen in compounds $\mathbf{2 ,} 8$ and $\mathbf{1 8 .}$

Compound 6 has shown higher selectivity against MDA-MB-435 than the other two cell lines. This facts, may be related to hydroxyl at position 3 in the phenyl ring, showing superior activity compared to the compound 4 .

A significant increase in cytotoxic activity was observed, when chlorine was introduced in para- position, since compound 2 was found more potent than 18 (meta-position). However, disubstituted 3,4-dichloro analogue 17 led to better activity, with $100 \%$ inhibition of tumor cell lines at $5 \mu \mathrm{mol} \mathrm{L}{ }^{-1}$. Interestingly, guanabenz (trade name, Wintensy ${ }^{\circledR}$ ) 12, a drug developed as an alpha-2 adrenergic agonist was significantly less active than compound 19.

Introduction of a second phenyl ring at para-14 or ortho-19 position led to a set of more potent compounds. This effect highlights the importance of the lipophilic character, which probably plays an important role in cytotoxic activity. In this sense, compound $\mathbf{1 0}$ was also highly active, since the presence of the bulky tert-butyl groups increased lipophilic character to the molecule, resulting in the best compound of the series.

Finally, the replacement of the phenyl ring by a heteroaromatic ring as in $\mathbf{1}$ and $\mathbf{1 3}$ led to activity decrease compared to compound $\mathbf{1 5 .}$

The most powerful compounds recognized in cytotoxic assays against human cancer cell lines at $5 \mu \mathrm{mol} \mathrm{L}^{-1}$ (Table II) were tested to obtain $I C_{50}$ values, which were compared to those of doxorubicin (control), as shown in Table III. Each assay was carried out in dupli- 
P. H. B. França et al.: Preliminary in vitro evaluation of the anti-proliferative activity of guanylhydrazone derivatives, Acta Pharm. 66 (2016) 129-137.

Table II. Cytotoxicity of guanylhydrazone derivatives against human cancer cell lines

\begin{tabular}{|c|c|c|c|c|c|}
\hline \multirow{2}{*}{ Compd. } & \multicolumn{3}{|c|}{ Inhibition (\%) } & & \multirow{2}{*}{$\begin{array}{c}\text { Yield } \\
(\%)\end{array}$} \\
\hline & HCT-8 & MDA-MB-435 & SF-295 & & \\
\hline 1 & - & - & 24.0 & & 71 \\
\hline 2 & 72.9 & 80.2 & 72.1 & & 71 \\
\hline 3 & 25.4 & 38.8 & 28.6 & & 89 \\
\hline 4 & 3.5 & 0.2 & 25.3 & & 93 \\
\hline 5 & - & 17.3 & 19.5 & & 98 \\
\hline 6 & - & 32.4 & 2.5 & & 92 \\
\hline 7 & - & - & 11.5 & & 95 \\
\hline 8 & 67.3 & 81.6 & 58.0 & & 83 \\
\hline 9 & - & 53.2 & 19.6 & & 81 \\
\hline 10 & 97.2 & 92.6 & 97.8 & & 85 \\
\hline 11 & 10.3 & 16.3 & 26.2 & & 71 \\
\hline
\end{tabular}


P. H. B. França et al.: Preliminary in vitro evaluation of the anti-proliferative activity of guanylhydrazone derivatives, Acta Pharm. 66 (2016) 129-137.

\begin{tabular}{|c|c|c|c|c|}
\hline 12 & 45.2 & 15.3 & 51.9 & 89 \\
\hline 13 & 42.1 & 29.8 & 52.0 & 91 \\
\hline 14 & 100 & 100 & 100 & 90 \\
\hline 15 & 28.3 & 26.5 & 24.7 & 89 \\
\hline 16 & 43.1 & 48.6 & 37.8 & 92 \\
\hline 17 & 100 & 100 & 100 & 92 \\
\hline 18 & 52.1 & 46.0 & 52.0 & 91 \\
\hline 19 & 96.9 & 95.2 & 93.8 & 92 \\
\hline 20 & 52.7 & 33.7 & 45.5 & 88 \\
\hline Doxorubicin & 97.3 & 96.9 & 87.6 & - \\
\hline
\end{tabular}

average value for $5 \mu \mathrm{mol} \mathrm{L}-1$ concentration $(n=3)$.

- Not active

cate and the means and respective confidence intervals were obtained by nonlinear regression analyses.

In order to investigate the effect of guanylhydrazone derivatives on non-tumor cells, compounds 10, 14, 17 and 19 were evaluated on macrophages J774 after 24 hours of incuba- 
P. H. B. França et al.: Preliminary in vitro evaluation of the anti-proliferative activity of guanylhydrazone derivatives, Acta Pharm. 66 (2016) 129-137.

Table III. $\mathrm{IC}_{50}$ values of guanylhydrazone derivatives in three human cancer cell lines

\begin{tabular}{cccccc}
\hline \multirow{2}{*}{ Cell line } & \multicolumn{5}{c}{$I C_{50}\left(\mu \mathrm{mol} \mathrm{\textrm {L } ^ { - 1 }}\right)$} \\
\cline { 2 - 6 } & $\mathbf{1 0}$ & $\mathbf{1 4}$ & $\mathbf{1 7}$ & $\mathbf{1 9}$ & Doxorubicin \\
\hline MDA-MB-435 & 3.4 & 4.2 & 0.4 & 9.8 & 0.8 \\
HCT-8 & 3.9 & 1.8 & 0.7 & 3.6 & 0.02 \\
SF-295 & 3.9 & 2.0 & 0.6 & 6.0 & 0.3 \\
\hline
\end{tabular}

tion and data obtained are displayed in Fig. 2. Results suggest that 10 shows low toxicity to non-tumor cells, because it is only able to decrease cell viability at a high concentration of $1 \mathrm{mmol} \mathrm{L}{ }^{-1}$. The other three compounds, 14, 17 and 19, showed higher cytotoxicity for non-tumor cells since they reduced cell viability at all tested concentrations (10, 100 and $\left.1000 \mu \mathrm{mol} \mathrm{L}{ }^{-1}\right)$. This confirms that compound $\mathbf{1 0}$ acts selectively on tumor cell lines and bears the most promising profile regarding cytotoxic activity.

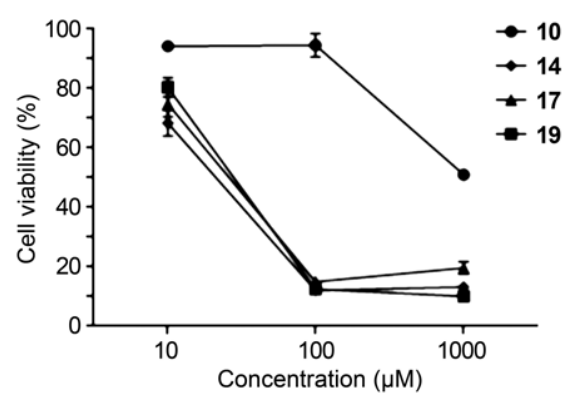

Fig. 2. J774 cell viability after $24 \mathrm{~h}$ in the presence of selected guanylhydrazone compounds (mean \pm $\mathrm{SD}, n=2)$.

\section{CONCLUSIONS}

The results reported in this study indicate that lipophilic guanylhydrazones 10, 14, 17 and 19 showed the highest cytotoxic activity against different human cancer cell lines. Compound 10 showed higher selectivity towards tumor cell lines and therefore it may be considered promising for the development of novel cytotoxic agents based on this scaffold.

Acknowledgments. - This work was supported by the Coordenação de Aperfeiçoamento de Pessoal de Nível Superior (CAPES), Conselho Nacional de Desenvolvimento Científico Tecnológico (CNPq), Fundação de Amparo à Pesquisa do Estado de Alagoas (FAPEAL), and Financiadora de Estudos e Pesquisa (FINEP).

Supplementary material is available from the authors upon request. 


\section{REFERENCES}

1. F. P. Schmidtchen and M. Berger, Artificial organic host molecules for anions, Chem. Rev. 97 (1997) 1609-1646; DOI: 10.1021/cr9603845.

2. U. E. W. Lange, D. Baucke, W. Hornberger, H. Mack, W. Seitz and H. W. Höffken, D-Phe-Pro-Arg type thrombin inhibitors: unexpected selectivity by modification of the P1 moiety, Bioorg. Med. Chem. Lett. 13 (2003) 2029-2033; DOI: 10.1016/S0960-894X(03)00347-0.

3. J. L. Jiménez Blanco, P. Bootello, J. M. Benito, C. O. Mellet and J. M. García Fernandez, Urea-, thiourea-, and guanidine-linked glycooligomers as phosphate binders in water, J. Org. Chem. 71 (2006) 5136-5143; DOI: 10.1021/jo060360q.

4. S. Ekelund, P. Nygren and R. Larsson, Guanidino-containing drugs in cancer chemotherapy: biochemical and clinical pharmacology, Biochem. Pharmacol. 61 (2001) 1183-1193; DOI: 10.1016/ S0006-2952(01)00570-6.

5. A. Andreani, M. Granaiola, A. Leoni, A. Locatelli, R. Morigi, M. Rambaldi, G. Lenaz, R. Fato, C. Bergamini and G. Farruggia, Potential antitumor agents. 37. Synthesis and antitumor activity of guanylhydrazones from imidazo[2,1-b]thiazoles and from the new heterocyclic system thiazolo[2', 3':2,3]imidazo[4,5-c]quinoline, J. Med. Chem. 48 (2005) 3085-3089; DOI: 10.1021/jm040888s.

6. A. L. LaFrate, J. R. Gunther, K. E. Carlson and J. A. Katzenellenbogen, Synthesis and biological evaluation of guanylhydrazone coactivator binding inhibitors for the estrogen receptor, Bioorg. Med. Chem. 16 (2008) 10075-10084; DOI: 10.1016/j.bmc.2008.10.007.

7. P. Ulrich and A. Cerami, Trypanocidal 1,3-arylene diketone bis(guanylhydrazone)s. Structureactivity relationships among substituted and heterocyclic analogues, J. Med. Chem. 27 (1984) 3540; DOI: 10.1021/jm00367a007.

8. J. R. Ring, F. Zheng, A. J. Haubner, J. M. Littleton and P. A Crooks, Improving the inhibitory activity of arylidenaminoguanidine compounds at the $\mathrm{N}$-methyl-D-aspartate receptor complex from a recursive computational-experimental structure-activity relationship study, Bioorg. Med. Chem. 21 (2013) 1764-1774; DOI: 10.1016/j.bmc.2013.01.051. 